\title{
HOME VISIT SEBAGAI STRATEGI PEMBELAJARAN AGAMA ISLAM PADA MASA PANDEMI COVID-19
}

\author{
Moh. Anik Mustofa', Rahmat Aziz ${ }^{2}$, Ahmad Fatah Yasin ${ }^{3}$ \\ UIN Maulana Malik Ibrahim Malang ${ }^{123}$ \\ email korespondensi: mohanikmustofa@gmail.com
}

\begin{abstract}
The Covid-19 pandemic has changed the face-to-face learning system to online. Online learning causes many obstacles, so teachers make home visits as an PAl learning strategy during the Covid-19 pandemic. This study aims to analyze the learning strategy of Islam in SMA Negeri 1 Glenmore, Banyuwangi Regency. This research adopts a qualitative approach with a case study method. Data were collected through observation, interviews and documentation. The data collected was then analyzed using the theory of Miles and Huberman, namely reducing, presenting and drawing conclusions. While the data validation technique is triangulation of data and data sources. This research shows that: a) the teacher prepares a lesson plan that is adapted to the students' condition in implementing the strategy home visit; $b$ ) worship activities, discipline, student character are important aspects that the teacher pays attention to when conducting lessons home visit; $c$ ) the evaluation process is home visit carried out in a simple way to measure learning achievement using the strategy home visit. This research must be followed up by testing the effectiveness of home visits in PAl learning during the Covid-19 pandemic.
\end{abstract}

Keywords: Covid-19, Home visi, PAl, Strategi

Abstrak: Pandemi Covid-19 mengubah sistem pembelajaran tatap muka menjadi online. Pembelajaran online yang menimbulkan banyak kendala, sehingga guru menjadikan home visit sebagai strategi pembelajaran PAI pada masa pandemi Covid-19. Penelitian ini bertujuan untuk menganalisis strategi pembelajaran Agama Islam di SMA Negeri 1 Glenmore Kabupaten Banyuwangi. Penelitian ini mengadopsi pendekatan kualitatif dengan metode studi kasus. Data dikumpulkan melalui observasi, wawancara dan dokumentasi. Data yang terkumpul kemudian dianalisis menggunakan teori Miles dan Huberman yaitu mereduksi, menyajikan dan penarikan kesimpulan. Sedangkan teknik validasi data dengan triangulasi data dan sumber data. Penelitian ini menunjukkan bahwa: a) guru menyusun rencana pembelajaran yang disesuaikan dengan kondisi siswa dalam pelaksanaan strategi home visit; b) kegiatan ibadah, kedisiplinan, karakter siswa menjadi aspek penting yang menjadi perhatian guru saat melakukan pembelajaran home visit; c) proses evaluasi home visit dilakukan dengan cara sederhana untuk mengukur ketercapaian pembelajaran menggunakan strategi home visit. Penelitian ini harus ditindaklanjuti dengan menguji efektivitas home visit dalam pembelajaran PAI pada masa pandemi Covid-19.

Kata kunci: Covid-19, Home visit, PAI, Strategi

\section{PENDAHULUAN}

Pendidikan Agama Islam (PAI) merupakan aspek penting dalam pembentukan spiritual siswa. Kekokohan pendidikan agama siswa menjadi pondasi pembangunan peradaban sebuah bangsa (Haqi et al., 2020: 33). Hal ini dilatarbelakangi oleh kualitas bangsa ditandai dengan kualitas pendidikan 
masyarakat bangsa tersebut (Syukri et al., 2019: 18). Faktor lain adalah karena pendidikan merupakan pendewasaan peserta didik agar dapat mengembangkan bakat, potensi, dan keterampilan yang dimiliki dalam menjalani kehidupan, oleh karena itu pendidikan didesain untuk memberikan pemahaman serta dapat meningkatkan prestasi belajar peserta didik (Huda \& Munastiwi, 2020: 82).

Pembelajaran Agama Islam mengalami perubahan besar setelah virus Covid-19 melanda di Indonesia sejak Maret 2020 lalu. Perubahan yang signifikan terjadi kepada pembelajaran yang awalnya tatap muka menjadi online (Ritonga \& Fitri, 2021: 104). Adanya pergantian sistem pembelajaran online menimbulkan perbincangan dan adaptasi baru terhadap proses pembelajaran. Tentu saja, hal ini salah satunya berdampak pada terganggunya sistem penyesuaian sosial siswa dan guru dalam pembelajaran (Fitri \& Abdul Latif, 2021: 29). Sehingga merekomendasikan home visit sebagai strategi pembelajaran pada masa pandemi Covid-19.

Berbagai metode pembelajaran telah banyak digunakan oleh sekolahsekolah dalam menyikapi pembelajaran pada masa pandemi Covid-19. Salah satu diantaranya adalah pembelajaran daring, pembelajaran ini dapat dimaknai sebagai suatu kegiatan belajar mengajar yang memanfaatkan jaringan atau koneksi internet sehingga terjalin komunikasi antara pendidik dan peserta didiknya tanpa melibatkan kontak fisik (Ritonga et al., 2020: 228). Namun pembelajaran menggunakan sistem daring tersebut tentunya memiliki berbagai kendala dalam pelaksanaannya karena pembelajaran ini mengharuskan guru, orang tua, maupun siswa mampu menggunakan internet (Nursyahidin, 2021: 154). Berbagai kendala yang menghambat pelaksanaan pembelajaran daring ini diantaranya minimnya pengetahuan dan keterampilan, serta kemampuan menggunkan internet, koneksi jaringan yang buruk, dan kurangnya fasilitas seperti handphone dan kuota internet. Karena banyaknya kendala yang dialami, banyak instansi pendidikan lebih memilih menggunakan pembelajaran home visit.

Kegiatan home visit yang dilakukan guru merupakan sarana untuk memberikan pelayanan terbaik kepada siswa. Strategi home visit juga 
bermaksud untuk menginformasikan kepada orang tua dan siswa terkait usahausaha yang harus dilakukan orang tua dalam mendukung pengembangan seluruh potensi, minat, dan bakat siswa selama di rumah (Elkugia et al., 2021: 2). Orang tua tidak menguasai pengetahuan tentang perkembangan anak sehingga dibutuhkan lembaga yang dapat memberikan stimulus dan memantau tahap perkembangan anak. Pelaksanaan metode home visit memerlukan perencanaan yang matang dari guru dan memerlukan kerja sama yang baik dengan orang tua siswa (Zaini et al., 2021: 155).

Dalam konsep pendidikan, keluarga memiliki peranan sangat penting. Keluarga lebih tahu karakter, kebiasaan, dan perilaku sehari-hari anak yang baik dan jelek. Mendatangi orang tua untuk menanyakan seluk-beluk anak menjadi masukan positif dalam menangani kasus anak. Membangun komunikasi yang baik dengan orang tua siswa tentu merupakan suatu keharusan bagi seorang guru (Sun'iyah, 2020: 6). Bentuk komunikasi tidak selalu terkesan kaku namun tetap dalam suasana kekeluargaan dan nyaman. Guru harus mampu menciptakan variasi pendekatan dalam berkomunikasi dengan orang tua siswa, salah satunya melalui strategi home visit.

Penelitian mengenai home visit telah banyak dilakukan. antara lain penelitian yang dilakukan oleh (Bali \& Musrifah, 2020: 137) menunjukkan bahwa pembelajaran di era pandemi Covid-19 mengalami kemerosotan sistem pendidikan siswa, sehingga strategi home visit penting dilakukan untuk memberikan stabilitas pembelajaran Agama kepada siswa. Home visit juga menjadi solusi preventif yang harus dilakukan oleh sekolah untuk mengurangi miskomunikasi antara guru dengan siswa dalam menyampaikan materi pembelajaran (Mokodompit, 2020: 119). Hubungan komunikasi yang baik antara guru dengan siswa memberikan efek positif terhadap pembelajaran online di tengah penyebaran pandemi Covid-19 (Sujarwo et al., 2020: 125). Selain itu, home visit memberikan hasil yang baik bagi perkembangan pengetahuan siswa dan mengurangi kesulitan guru dalam menyampaikan pembelajaran, siswa dan orang tua (Ibda \& Laeli, 2021: 13). Namun untuk memudahkan guru dalam menyampaikan pembelajaran kepada siswa, guru 
dituntut memiliki keterampilan dalam menggunakan teknologi sebagai media pembelajaran dalam menerapkan strategi home visit (Makmun, 2021: 20).

Berdasarkan hasil analisis penelitian terdahulu, penting dilakukan kajian mengenai strategi home visit dalam pembelajaran Agama Islam. Hal ini didasari karena kebutuhan guru, siswa dan orang tua yang dituntut mampu mengeksplorasi pembelajaran yang diberikan setiap waktu. Sehingga pembelajaran pada masa pandemi Covid-19 harus didesain dengan baik yang memberikan manfaat langsung kepada siswa. Penelitian ini diharapkan menjadi acuan bagi guru dan sekolah di Indonesia dalam menyampaikan pembelajaran Agama Islam menggunakan strategi home visit pada masa pandemi Covid-19.

\section{METODE}

Penelitian ini menggunakan desain penelitian kualitatif yang bertujuan untuk mendeskripsikan fenomena secara mendalam. Sedangkan metode yang digunakan adalah studi kasus. Penelitian studi kasus berfungsi untuk melihat objek secara komprehensif melalui deskripsi narasi untuk mendapat informasi secara detail (Yin, 2011: 21). Data dikumpulkan melalui observasi, wawancara, dan dokumentasi, yaitu peneliti langsung turun ke lapangan untuk mendapatkan data yang dibutuhkan (Neuman, 2014: 20).

Peneliti melakukan pengamatan terhadap proses home visit pada pembelajaran Agama Islam di SMA 1 Glenmore Kabupaten Banyuwangi. Informan dalam penelitian ini adalah guru pelajaran Agama Islam untuk mendapatkan informasi tentang proses penerapan strategi home visit dalam pembelajaran Agama Islam pada masa pandemi Covid-19. Data yang diperoleh kemudian dianalisis berdasarkan teori Miles and Huberman, dengan mereduksi data, menyajikan dan memverifikasi secara detail sehingga diperoleh kesimpulan (Miles \& Huberman, 1994: 16). Selama proses pengumpulan data, peneliti mencatat fenomena yang ditemukan dalam proses pembelajaran Agama Islam. Setelah data diperoleh, peneliti memilih data yang mendukung penelitian dan membuang data yang tidak dibutuhkan. Terakhir, peneliti melakukan teknik triangulasi data dan sumber data untuk memperoleh validitas data yang dipaparkan. Atas tahapan di atas, maka penelitian ini dapat ditelaah 
secara integral sehingga menghasilkan informasi sesuai dengan tujuan penelitian. Skema dalam penelitian ini dapat dilihat pada tabel di bawah ini:

\begin{tabular}{|c|c|c|}
\hline Pendekatan & $\Longrightarrow$ & Kualitatif \\
\hline Metode & $\longrightarrow$ & Studi Kasus \\
\hline Teknik Pengumpulan Data & ᄃ & $\begin{array}{l}\text { Observasi, Wawancara dan } \\
\text { Dokumentasi }\end{array}$ \\
\hline Teknik Validasi Data & — & $\begin{array}{l}\text { Tri Angulasi Data dan } \\
\text { Sumber Data }\end{array}$ \\
\hline
\end{tabular}

Tabel 1: Skema Metodologi Penelitian

\section{HASIL DAN PEMBAHASAN}

Implementasi home visit menjadi aspek prioritas lembaga pendidikan untuk menyampaikan materi pelajaran kepada siswa. Layanan home visit menjadi suatu cara yang dilakukan oleh guru selaku penanggung jawab layanan pembelajaran untuk mencari tahu bagaimana kondisi pembelajaran siswa, orang tua dan memberikan solusi yang tepat bagi siswa (Sabela et al., 2021: 19). Dalam hal ini guru dapat memperoleh beberapa data yang dapat digunakan untuk memaksimalkan layanan pembelajaran dan dapat mengajak orang tua atau anggota keluarga lainnya berpartisipasi dalam memenuhi kebutuhan siswa dalam proses pembelajaran (Setiyanto et al., 2021: 84). Kunjungan rumah atau home visit merupakan program bimbingan pembelajaran tatap muka yang dilakukan oleh guru ke rumah-rumah siswa untuk menyelesaikan permasalahan pembelajaran siswa pada masa pandemi Covid19 dengan sistem pembelajaran online. Melalui home visit diharapkan siswa menerima informasi pembelajaran bermakna dalam pembelajaran Agama Islam.

\section{a. Perencanaan home visit pada masa pandemi Covid-19}

Strategi home visit harus direncanakan dengan baik untuk memperoleh hasil yang maksimal. Perencanaan pembelajaran home visit merupakan satu persiapan yang dilakukan guru untuk melaksanakan proses pembelajaran kepada siswa. Pembelajaran dilakukan dengan menerapkan prinsip-prinsip 
belajar, dan pembelajaran juga dilakukan diawali dengan proses perencanaan, pelaksanaan dan evaluasi (Putra et al., 2020: 142). Perencanaan dapat menjadi indikator perbaikan kualitas pembelajaran kedepannya. Melalui perencanaan yang baik akan memperbaiki kualitas pembelajaran dan penilaian yang baik pula.

Pelaksanaan home visit yang berlangsung di SMA Negeri 1 Glenmore dilakukan dengan perencanaan yang matang. Dalam perencanaan pembelajaran home visit, guru juga dituntut menyusun silabus dan Rencana Pelaksanaan Pembelajaran (RPP) sebagai pedoman dalam proses pembelajaran. Perencanaan pembelajaran dimaksud bersumber dari buku paket pendidikan Agama Islam sebagai sumber primer pembelajaran bagi siswa.

Kegiatan home visit merupakan kegiatan yang didalamnya termasuk dalam kegiatan pembelajaran PAI. Dengan demikian, perencanaan yang dibuat oleh guru mata pelajaran PAI dalam pelaksanaan home visit di SMA Negeri 1 Glenmore harus menyesuaikan dengan kebutuhan peserta didik yang disesuaikan dengan materi pelajaran yang terdapat dalam buku paket siswa. Ketentuan lain adalah perencanaan pelaksanaan home visit yang disusun oleh guru harus disesuikan dengan ketentuan yang ditetapkan di SMA Negeri 1 Glenmore, yaitu: a) pembelajaran PAI berorientasi kepada pendidikan karakter siswa; b) pembelajaran ditekankan kepada pendampingan ibadah siswa, seperti sholat Dhuha, dan Dzuhur; c) memulai pembelajaran dengan do'a dan membaca Al-Qur'an. Perencanaan tersebut dapat disusun berdasarkan kebutuhan dalam jangka waktu tertentu sesuai dengan keinginan (Amalia, 2016: 94-95). Namun yang lebih utama adalah perencanaan yang telah dibuat dapat dilaksanakan dengan mudah dan tepat sasaran.

Perumusan perencanaan home visit di SMA Negeri 1 Glenmore dilakukan dengan cara yang sederhana. Pada dasarnya, perencanaan home visit memberikan kemudahan bagi guru dan siswa dalam menyampaikan dan menerima pesan pembelajaran. Sehingga guru harus memperhatikan tingkat pengetahuan dan keterampilan berpikir siswa dalam menyusun perencanaan pembelajaran (Ibrahim et al., 2019: 33). Sebagaimana yang dibahas Prabowo, 
(2010: 6) dalam prinsip-prinsip perencanaan pembelajaran yang pertama memiliki visibilitas, yakni dalam melakukan perencanaan harus diperhitungkan bagaimana perencanaan tersebut dilakukan, yang kedua beracuan pada masa yang akan datang, yakni perencanaan yang dibuat adalah apa yang diupayakan untuk dapat dicapai dalam kurun waktu yang akan datang, yang ketiga berpijak pada fakta artinya perencanaan yang dibuat memperhitungkan berbagai realitas dan kondisi yang ada di sekolah utamanya yang berkaitan dengan kemampuan siswa, dan kemampuan sekolah menyediakan sumber daya yang mumpuni.

Home visit menjadi pilihan baik bagi guru di tengah gencatan wabah pandemi Covid-19. Alasan SMA Negeri 1 Glenmore memberlakukan home visit agar siswa memperoleh pembelajaran dan dapat berdiskusi dengan guru terkait pembelajaran secara langsung. Selain memberikan materi pelajaran, guru juga menanamkan sikap disiplin kepada siswa saat melakukan home visit. Sebagaimana hasil wawancara peneliti kepada salah satu informan:

"Kegiatan home visit dilatarbelakangi oleh keinginan kuat dari sekolah untuk tetap memberikan bimbingan pembelajaran langsung kepada siswa. aktivitas ibadah siswa menjadi salah satu aspek yang menjadi perhatian guru saat melakukan home visit. Guru mendampingi kegiatan ibadah siswa selama berada di rumah. Kegiatan home visit tidak selalu lancar sesuai keinginan, namun selalu mendapat kendala dalam hal teknis di lapangan, seperti hujan, sarana prasarana sekolah yang terbatas. Orientasi home visit mengarah kepada peningkatan kedisiplinan siswa saat berada dalam pengawasan guru di rumah. Karena sikap disiplin menjadi bekal utama bagi siswa untuk menghadapi masa depan mereka yang lebih baik." (Suyono, wawancara, 2021).

Home visit memberikan akses kepada guru untuk mengetahui ketercapaian pembelajaran yang disampaikan. Home visit juga menjadi strategi bagi guru untuk mengembangkan kedekatan emosional guru dengan siswa, dan orang tua (Kim-Godwin et al., 2013: 67). Isu yang berkembang di 
masyarakat bahwa pembelajaran online yang banyak digelar oleh sekolah memberikan dampak negatif terhadap pengetahuan siswa. sebagaimana wawancara peneliti kepada informan:

"Dasar diterapkanya home visit karena guru merasa kesulitan memilih media yang tepat untuk menyuguhkan materi pembelajaran secara online. Hasil evaluasi pembelajaran online memberikan gambaran bagi guru bahwa kemerosotan pengetahuan siswa semakin tampak nyata. Karena siswa merasa kurang memahami materi yang disajikan secara online. Sehingga kegiatan home visit yang dilakukan di SMA Negeri 1 Glenmore berupaya memberikan sistem pelajaran terbaik dengan cara langsung menemui siswa di rumah mereka masing-masing." (Saeqoni, wawancara, 2021).

\section{b. Pelaksanaan home visit di masa pandemi Covid-19}

Pelaksanaan pembelajaran merupakan aktivitas tindak lanjut dari perencanaan yang telah disusun sebelumnya. Pelaksanaan berjalan sesuai dengan perencanaan yang dibuat, semakin bagus perencanaan, maka semakin baik pula pelaksanaannya. Strategi home visit yang telah direncanakan untuk selanjutnya dilaksanakan sesuai dengan rencana yang telah disusun pembelajaran pada hakikatnya adalah pelaksanaan dari perencanaan yang telah disusun sebelumnya. Dalam proses pelaksanaan, keterampilan guru dalam mengelola media, sumber belajar, metode menjadi hal penting yang harus dimiliki. Guru yang sukses memberikan materi pelajaran kepada siswanya adalah guru yang menguasai strategi pembelajaran dan mampu menuntun siswa mengikuti jalannya proses pembelajaran.

Pelaksanaan home visit di SMA Negeri 1 Glenmore berlangsung setelah keluarnya izin penerapan kebijakan new normal. Home visit dilakukan hanya berlangsung dua hari dalam satu minggu sesuai dengan jadwal mata pelajaran yang telah disusun sebelumnya. Berikut wawancara peneliti dengan salah satu informan: 
"Kegiatan home visit ini dilaksanakan semenjak diperbolehkannya kegiatan belajar mengajar pasca new normal. Home visit ini dilaksanakan setiap hari Senin dan Rabu sesuai dengan jam mata pelajaran PAI. Para guru yang bertugas melaksanakan pembelajaran home visit berangkat menuju lokasi pembelajaran dan membuatkan laporan pelaksanaannya. Temuan kendala dan kemudahan yang ditemukan guru saat melaksanakan home visit akan menjadi masukan kepada sekolah untuk ditindaklanjuti sesuai dengan kebutuhan guru." (Saeqoni, wawancara, 2021)

Pelaksanaan home visit dalam pembelajaran PAl diarahkan kepada aktivitas ibadah siswa. para guru PAl mengarahkan siswa untuk selalu melakukan ibadah-ibadah di rumah seperti halnya ibadah yang biasa mereka lakukan di sekolah. Kegiatan ibadah menjadi program unggulan sekolah yang bertujuan untuk membentuk generasi siswa yang berkarakter dan memiliki keimanan yang kuat sebagai bekal hidup mereka pada masa yang akan datang. Berikut pengakuan dari salah satu informan:

"Di SMA Negeri 1 Glenmore ini ada kegiatan dhuha wajib. Seluruh siswa wajib melaksanakan shalat dhuha berjamaah di masjid. Namun program shalat dhuha terhenti karena penyebaran pandemi Covid-19. Selain itu, siswa juga diwajibkan melaksanakan solat Jum'at berjamaah di masjid sekolah. Kegiatan-kegiatan keagamaan yang disebutkan tadi diharapkan dapat terlaksana kembali melalui strategi pembelajaran home visit. Singkatnya, home visit ini sangat membantu guru melakukan kontrol terhadap aktivitas ibadah siswa. kebiasaan baik itu telah menjadi rutinitas yang dilakukan siswa selama kegiatan home visit, seperti shalat Dzuhur berjamaah tanpa harus diperintah guru terlebih dahulu." (Suyono, wawancara, 2021).

Pembelajaran home visit membutuhkan metode dan media sebagai penunjang sampainya materi yang diajarkan kepada siswa. Strategi home visit yang dilaksanakan di SMA Negeri 1 Glenmore mengadopsi strategi 
pembelajaran dengan menyajikan teori dan praktik kepada siswa. Saat menyajikan materi kepada siswa, guru menggunakan metode ceramah. Aktivitas pembelajaran di luar ruangan melalui praktik yang langsung didemonstrasikan oleh siswa. Pembelajaran berorientasi kepada siswa menjadi arah pembelajaran kekinian yang sangat bermakna bagi siswa, karena siswa bisa merasakan aktivitas pembelajaran yang baru diajarkan (Hayudiyani et al., 2020: 90).

Dalam pembelajaran home visit, guru hendaknya menyusun langkahlangkah strategis yang menjadi pedoman pelaksanaan kegiatan home visit. Langkah-langkah home visit yang dilakukan guru di SMA Negeri 1 Glenmore adalah sebagai berikut: a) guru mempersiapkan materi pelajaran yang akan disampaikan kepada siswa; b) guru menginformasikan kegiatan home visit kepada siswa melalui group Whatsapp; c) guru berangkat menuju lokasi home visit sesuai jadwal yang telah ditentukkan oleh sekolah; d) guru mengumpulkan siswa dalam satu kelompok dan memulai pembelajaran dengan berdoa; e) guru menyampaikan tujuan pembelajaran selama home visit; f) guru dan siswa melakukan diskusi yang berkaitan dengan materi pelajaran. Langkah-langkah pembelajaran home visit mengarahkan guru dan siswa kepada jalannya aktivitas pembelajaran sesuai dengan tujuan yang diharapkan (Ilhan et al., 2019: 61).

\section{c. Evaluasi home visit di masa pandemi Covid-19}

Evaluasi merupakan salah satu komponen penting dalam kegiatan pembelajaran. Dalam pelaksanaan home visit, guru perlu melakukan evaluasi tentang kemanfaatan strategi pembelajaran home visit sebagai solusi yang tepat untuk mengatasi permasalahan belajar siswa. Melalui proses evaluasi guru mengetahui kelebihan dan kekurangan pembelajaran, dampak positif dan negatif strategi home visit, beserta solusi yang tepat untuk mengatasi permasalahan pembelajaran yang sedang dihadapi siswa (Lukinah, 2021: 130).

Evaluasi pelaksanaan home visit di SMA Negeri 1 Glenmore dilakukan untuk mengukur pengetahuan siswa tentang materi yang diajarkan. Evaluasi ini menjadi instrumen penting bagi guru untuk melihat perubahan pengetahuan siswa sebelum diberi materi PAl dengan setelah siswa mempelajari materi PAI. 
Evaluasi merupakan salah satu komponen penting yang harus ditempuh oleh guru untuk mengetahui keefektifan pembelajaran (Huth et al., 2020: 1020). hasil yang diperoleh dari evaluasi dapat dijadikan sebagai masukan perbaikan sistem pembelajaran dan untuk menyempurnakan kekurangan pembelajaran yang dilakukan.

Dalam setiap pembelajaran seorang guru dituntut untuk melaksanakan evaluasi. Bentuk evaluasi pembelajaran dilaksanakan dalam home visit berupa penilaian tes unjuk kerja dan penilaian non tes. Penilaian tes unjuk kerja yang harus diikuti siswa antara lain ujian praktik di akhir pembelajaran, sedangkan untuk penilaian non tes dilaksanakan dengan cara guru mengamati sikap dan perilaku dalam keseharian siswa yang berhubungan dengan karakter, aktivitas ibadah dan kedisiplinan di lapangan maupun keaktifan mengikuti pembelajaran yang berkaitan dengan kegiatan pelaksanaan home visit.

Pelaksanaan home visit yang dilakukan dengan penilaian tentang keefektifan layanan yang telah diberikan oleh guru. Namun, dalam proses evaluasi home visit, ditemukan faktor pendukung dan penghambat jalannya strategi pembelajaran home visit pada masa pandemi Covid-19 (Hwang \& Kim, 2020: 89). Faktor pendukung tersebut bersumber dari terjalinnya komunikasi yang baik antara guru, siswa dan manajemen sekolah. Sedangkan faktor penghambat strategi pembelajaran home visit adalah akses rumah siswa yang jauh, sarana pembangunan akses jalan ke rumah siswa yang butuh perbaikan, sarana prasarana sekolah yang kurang memadai, seperti wifi, dll. Keberhasilan pelaksanaan home visit, fasilitas menjadi faktor utama yang harus dilengkapi demi terwujudnya tujuan pelaksanaan home visit pada masa pandemi Covid19.

\section{KESIMPULAN}

Berdasarkan pemaparan data di atas, dapat disimpulkan bahwa: a) perencanaan strategi home visit dalam pembelajaran PAI pada masa pandemi Covid-19 disesuaikan dengan kebutuhan siswa. perencanaan home visit menjadi begitu penting, karena berpengaruh terhadap kualitas pelaksanaannya; b) pelaksanaan home visit dilakukan sesuai dengan jadwal pembelajaran PAI, 
yaitu dua kali dalam satu minggu, hari Senin dan Rabu. Dalam pelaksanaan home visit, kegiatan ibadah siswa menjadi aspek prioritas yang harus didampingi guru, seperti shalat Dhuha, membaca Al-Qur'an, sholat Jum'at dan Dzuhur; c) evaluasi pembelajaran home visit dilakukan dengan sederhana, kegiatan evaluasi untuk mengukur ketercapaian tujuan pembelajaran menggunakan strategi home visit, melihat dampak negatif dan positif strategi home visit, untuk mengetahui kekurangan dan kelebihan strategi home visit, sebagai instrumen guru melakukan perbaikan sistem pembelajaran. penelitian ini menunjukkan bahwa strategi home visit mempermudah penyampaian materi PAI kepada siswa, ditandai dengan terjalinnya komunikasi yang baik antara guru, siswa, dan orang tua sebagai pembimbing siswa ketika berada di rumah. Untuk melengkapi penelitian ini yang hanya melihat pelaksanaan strategi home visit, diharapkan adanya penelitian lanjutan yang menguji efektivitas strategi home visit dalam pembelajaran PAI pada masa pandemi menggunakan metode yang lebih detail.

\section{DAFTAR PUSTAKA}

[1] A. L. Haqi, A. F. Haikal, M. Musawamah, S. Nikmah, and L. Walidiya, "Implementasi Pendidikan Agama Islam Sekolah Indonesia Den Haag," al-Iltizam J. Pendidik. Agama Islam, vol. 5, no. 2, p. 33, 2020, doi: 10.33477/alt.v5i2.1752.

[2] I. I. F. Syukri, S. S. Rizal, and M. D. Al Hamdani, "Pengaruh Kegiatan Keagamaan Terhadap Kualitas Pendidikan," J. Penelit. Pendidik. Islam, vol. 7, no. 1, p. 17, 2019, doi: 10.36667/jppi.v7i1.358.

[3] K. Huda and E. Munastiwi, "Strategi Orang Tua Dalam Mengembangkan Bakat Dan Kreativitas Anak di Era Pandemi Covid-19," J. Pendidik. Glas., vol. 4, no. 2, p. 80, 2020, doi: 10.32529/glasser.v4i2.670.

[4] A. W. Ritonga and A. Fitri, "Maharah Qira'ah Learning Strategy for Integrated Islamic Elementary School (SDIT) Students During Covid-19 Pandemic," J. Elem. Kaji. Teor. dan Has. Penelit. Pendidik. Sekol. Dasar, vol. 4, no. 2, pp. 103-107, 2021, doi: 10.31764/elementary.v4i2.4501.

[5] M. Fitri and M. Abdul Latif, "Adaptive Learning for Early Childhood 
Education during the Covid-19 Pandemic in Aceh Jaya District: Online vs. Offline," Al-Athfal J. Pendidik. Anak, vol. 7, no. 1, pp. 27-38, 2021, doi: 10.14421/al-athfal.2021.71-03.

[6] A. W. Ritonga et al., "E-learning Process of Maharah Qira'ah in Higher Education During the Covid-19 Pandemic," Int. J. High. Educ., vol. 9, no. 6, pp. 227-235, 2020, doi: 10.5430/ijhe.v9n6p227.

[7] R. Nursyahidin, "Learning Innovation of Islamic Education in Covid-19 Pandemic," J. Pendidik. Agama Islam, vol. 18, no. 1, pp. 145-166, 2021, doi: 10.14421/jpai.2021.181-08.

[8] N. Elkugia, M. E. Crocker, J. W. Stout, K. Bolt, B. J. Weiner, and C. B. Kramer, "Development of an Asthma Home-Visit Training Program for Community Health Workers and Their Supervisors in Washington State," Front. Public Heal., vol. 9, no. June, pp. 1-9, 2021, doi: 10.3389/fpubh.2021.674843.

[9] H. Zaini et al., "Covid-19 and Islamic Education in School: Searching for Alternative Learning Media," Webology, vol. 18, no. 1, pp. 154-165, 2021, doi: 10.14704/WEB/V1811/WEB18080.

[10] S. L. Sun'iyah, "Sinergi Peran Guru Dan Orang Tua Dalam Mewujudkan Keberhasilan Pembelajaran Pai Tingkat Pendidikan Dasar di Era Pandemi Covid-19," DAR EL-ILMI J. Stud. Keagamaan, Pendidik. dan Hum., vol. 7, no. 2, pp. 1-16, 2020.

[11] M. M. E. I. Bali and M. Musrifah, "The Problems of Application of Online Learning in the Affective and Psychomotor Domains During the Covid-19 Pandemic," J. Pendidik. Agama Islam, vol. 17, no. 2, pp. 137-154, 2020, doi: 10.14421/jpai.2020.172-03.

[12] I. S. Mokodompit, "Home Visit Sebagai Refleksi Kurikulum Darurat Covid19: Kesiapan Guru, Respon Siswa, Materi dan Hasil Belajar di Madrasah Tsanawiyah," J. Manaj. dan Pendidik. Islam, vol. 6, no. 2, pp. 119-131, 2020, [Online]. Available: journal.unipdu.ac.id/index.php/dirasat/index.

[13] S. Sujarwo, S. Sukmawati, A. Akhiruddin, R. Ridwan, and S. Siradjuddin, "An Analysis of University Students' Perspective On Online Learning in The Midst of Covid-19 Pandemic," J. Pendidik. dan Pengajaran, vol. 53, 
no. 2 , p. 125 , 2020, doi: $10.23887 / j p p . v 53 i 2.24964$.

[14] H. Ibda and D. N. Laeli, "Student Learning Outcomes During the Covid-19 Pandemic Through Home Visit Study at MI Salafiyah Kranggan," AtThullab J. Pendidik. Guru Madrasah Ibtidaiyah, vol. 5, no. 1, pp. 12-22, 2021, doi: 10.30736/atl.v5i1.451.

[15] S. Makmun, "Kombinasi Pembelajaran Media Daring dengan Strategi Home Visit pada Masa Pandemi Covid-19 pada Sekolah Dasar Negeri 1 Batu Layar," J. IIm. Telaah, vol. 6, no. 1, pp. 20-25, 2021, doi: 10.31764/telaah.v6i1.3351.

[16] R. K. Yin, Qualitative Research From Start to Finish. New York: The Guilford Press, 2011.

[17] W. L. Neuman, Social Research Methods: Qualitative and Quantitative Research. Harlow: Pearson Education Limited, 2014.

[18] M. B. Miles and A. M. Huberman, Qualitative Data Analysis. Los Angeles: Sage Publications, 1994.

[19] R. A. Sabela, P. S. Anggraeni, and A. Muhid, "Home Visit Services In Overcoming Learning Motivation Problems In Students: Literature Review," Suluh J. Bimbing. Dan Konseling, vol. 6, no. 2, pp. 17-23, 2021, doi: 10.33084/suluh.v6i2.2463.

[20] A. Setiyanto, Subandi, and M. K. Fadillah, "The Problems of Islamic Education Learning at Islamic Vocational High School Raden Fatah Tugumulyo, South Sumatra," Bull. Pedagog. Res., vol. 1, no. 1, pp. 83105, 2021.

[21] P. Putra, F. Y. Liriwati, T. Tahrim, S. Syafrudin, and A. Aslan, "The Students Learning from Home Experiences during Covid-19 School Closures Policy In Indonesia," J. Iqra' Kaji. IImu Pendidik., vol. 5, no. 2, pp. 30-42, 2020, doi: 10.25217/ji.v5i2.1019.

[22] H. Amalia, "Implementasi Home Visit dalam Upaya Meningkatkan Pembelajaran PAI di SDIT Al-Azhar Kediri," Didakt. Relig., vol. 4, no. 1, pp. 77-106, 2016, doi: 10.30762/didaktika.v4.i1.p77-106.2016.

[23] B. Ibrahim, Z. Abidin, and A. J. Putra, "Profesionalisme Guru PAI Berdasarkan Analisis Komponen Kurikulum 2013 di Aceh," al-Iltizam J. 
Pendidik. Agama Islam, vol. 4, no. 2, pp. 44-65, 2019, doi: 10.33477/alt.v4i2.1007.

[24] S. L. Prabowo, Perencanaan Pembelajaran. Malang: UIN Maliki Press, 2010.

[25] Y. S. Kim-Godwin, K. R. Livsey, D. Ezzell, and C. Highsmith, "Home Visit Simulation Using a Standardized Patient," Clin. Simul. Nurs., vol. 9, no. 2, pp. e55-e61, 2013, doi: 10.1016/j.ecns.2011.09.003.

[26] M. Hayudiyani, B. R. Saputra, M. A. Adha, and N. S. Ariyanti, "Strategi Kepala Sekolah Meningkatkan Mutu Pendidikan Melalui Program Unggulan Sekolah," J. Akuntabilitas Manaj. Pendidik., vol. 8, no. 1, pp. 89-95, 2020, doi: 10.21831/jamp.v8i1.30131.

[27] F. Ilhan, B. Ozfidan, and S. Yilmaz, "Home Visit Effectiveness on Students' Classroom Behavior and Academic Achievement," J. Soc. Stud. Educ. Res., vol. 10, no. 1, pp. 61-80, 2019.

[28] I. Lukinah, "The Effect of Home Visit on the Learning Outcomes of Class 3 Students in SD IQ Al-Islam," ETUDE J. Educ. Res., vol. 1, no. 4, pp. 128-134, 2021.

[29] K. Huth et al., "Visiting Jack: Mixed Methods Evaluation of a Virtual Home Visit Curriculum With a Child With Medical Complexity," Acad. Pediatr., vol. 20, no. 7, pp. 1020-1028, 2020, doi: 10.1016/j.acap.2020.05.001.

[30] W. J. Hwang and J. A. Kim, "Development and Evaluation of a Home-visit Simulation Scenario for Elderly People with Diabetes Mellitus Who Live Alone," J. Community Health Nurs., vol. 37, no. 2, pp. 89-102, 2020, doi: 10.1080/07370016.2020.1736399. 